ANDREAS AND THE AMBIGUITY OF COURTLY LOVE 
This page intentionally left blank 


\section{PAOLO CHERCHI}

Andreas and

the Ambiguity of

Courtly Love

UNIVERSITY OF TORONTO PRESS

Toronto Buffalo London 
www.utppublishing.com

(C) University of Toronto Press Incorporated 1994

Toronto Buffalo London

Printed in Canada

Toronto Italian Studies

ISBN 0-8020-0577-2

(

Printed on acid-free paper

\section{Canadian Cataloguing in Publication Data}

Cherchi, Paolo

Andreas and the ambiguity of courtly love

(Toronto Italian Studies)

Includes bibliographical references and index.

ISBN 0-8020-0577-2

1. Courtly love in literature. 2. André le chapelaine. De amore et amoris remedio. 3. Provençal poetry. History and criticism. 4. Troubadours.

I. Title. II. Series.

PA8250.A236Z64 1994 849'.1209'354 C93-095581-1

University of Toronto Press acknowledges the financial assistance to its publishing program of the Canada Council and the Ontario Arts Council. 
To my wife, Judy 
This page intentionally left blank 